\title{
THE ROLE OF CORPORATE SOCIAL RESPONSIBILITY DICLOSURE IN MODERATING THE EFFECT OF CAPITAL STRUCTURE ON FIRM VALUE
}

\author{
Setiawati A.A.S.M.D., Budiartha I K., Ratnadi N.M.D., Sari M.M.R. \\ University of Udayana, Indonesia \\ *E-mail: miradewis@gmail.com
}

\begin{abstract}
This study aims to prove empirically the effect of capital structure on firm value moderated by CSR disclosure. Signaling theory is used as the theoretical basis in this study. The population is all companies in the mining sector of Indonesia Stock Exchange during 20122016. Sampling method uses is purposive sampling method. Hypotheses were tested with Moderated Regression Analysis (MRA) with a classical assumption test first. The result of the analysis shows that CSR disclosure variable is able to moderate the effect of capital structure on firm value. It means that more companies expose their social responsibility to the environment and society will further strengthen the interest of investors to invest in companies that are considered environmentally friendly and see CSR activities as a guide to assess the potential sustainability of a company, but when the company's capital structure where the proportion of debt more than its equity will be able to lower the firm value because investors judge the company is too risky financial difficulties. If the company's debt can be reduced then it can increase the firm value.
\end{abstract}

\section{KEY WORDS}

Capital structure, firm value, disclosure, signaling theory.

Firm value is a value that reflects what price investors can afford for a company. The value of the firm in this study is measured by market to book ratio or market value comparison to the book value of a company's equity used to find out how much the price per share is in the market compared to the book value per share (Weston \& Copeland, 1992; Apriada , 2013).

The welfare of shareholders is effect by the financial decisions made by the management. The financial manager as the party responsible, has an important role in determining financial decisions. One of the important decisions faced by financial managers is the decision of funding or the determination of capital structure. The amount of funds required each company is not the same, tailored to the conditions of each company.

The capital structure is the proportion of long-term debt financing and equity financing. If the company's capital needs are increased, while the funds are limited then the company has no choice but to use the funds from outside, either in the form of debt or issuing bonds to meet its capital needs (Brealey, et al., 2007). Therefore, the problem of capital structure is a very important issue for the company, because the funding policy determines the company's operations.

The type of funding chosen will effect the company's investment decision. In addition, capital structure decisions directly affect the amount of risk that must be borne by the shareholders, as well as the magnitude of the expected rate of return or profit. The wrong decision about the capital structure will cause the company to experience financial distress or even to bankruptcy. Conversely, appropriate funding decisions will improve the cost efficiency of capital and firm value. Therefore, choosing funding strategy becomes important in establishing optimal capital structure.

Research on capital structure aims to determine a model that can explain the company's funding decisions. Theoretically, the factors that effect the decision of the funding structure are difficult to measure (Sulistyowati, 2009). Firm funding sources can be obtained from both internal and external sources. Trade off theory itself is more inclined to the use of external funding sources. The capital structure policy involves a trade off between return and 
risk (Brigham \& Houston, 2001: 5). Using debt means increasing the risk borne by shareholders and also enlarging the rate of return. Static trade off theory states that the balance between the interested tax shield with leverage related costs such as financial distress and bankruptcy will be able to optimize the capital structure (Ramlal, 2009). Trade off theory explains that the manager's decision in determining the order of structure and source of funding begins with the use of debt.

In this research the moderating variable used is Corporate Social Responsibility disclosure hereinafter abbreviated as CSR which is calculated using content analysis method. CSR activity is a form of firm responsibility to improve social and environmental problems that occur due to the company's operational activities; therefore CSR is instrumental to increase the firm value. Companies should regard CSR as a profitable longterm strategy, not as a harmful activity (Heinkel, et al., 2001).

By expressing CSR the company will not get direct profit, which is expected from the activity is a benefit in the form of image or firm reputation. To companies that have gone public or capital market issuers, the reputation of the company tends to increase the assessment of investors, which in turn will facilitate the company to obtain capital. Reputation will increase firm value implicitly and can be sold to its stakeholders (Dobson, 1989).

In Indonesia itself, research on corporate social responsibility as one of the firm reputation proxies is done by (Suta, 2005) which analyzes the effect between firm reputation and market performance. The study begins with the analysis of factors and dimensional reduction of some of the adaptation reputation criteria of AMAC's reputation model and other methods called "Harris Fombrun Reputation Quotient (RQ)" resulting in several new factors forming the company's reputation, i.e. social responsibility, accounting measurements, firm governance, and reputation. This study shows that there is a effect which is positive between the firm reputation with the firm market performance, where in measuring market performance, used four measurement variables, namely stock liquidity, stock price growth, stock distribution, and market capitalization. The results of this study show that corporate governance and reputation of top management have a very significant effect on the market performance of the firm followed by social responsibility and accounting measures.

\section{LITERATURE REVIEW}

Financial information is conveyed by the company through the financial statements regarding the accountability of the management of the economic resources it manages. The financial information disclosed in the financial statements can reflect how large the value of a company is through its stock market price (Fama, 1978). Soliha and Taswan (2002) stated that the higher the stock price the higher the firm value. High firm value is the desire of the company owner, high firm value indicates high shareholder wealth.

The welfare of shareholders is effect by the financial decisions made by the management. The financial manager as a responsible party has an important role in determining financial decisions such as funding decisions or capital structure determination. The amount of funds required each company is not the same, tailored to the conditions of each company. If the company's capital needs are increasing, while the funds are limited then the company has no choice but to use the funds that come from outside, either in the form of debt or issuing bonds to meet their capital needs. Therefore, the problem of capital structure is a very important issue for the company, because the funding policy determines the company's operations.

Some researchers mention many factors that determine the firm value, one of which is the capital structure. According to Brigham \& Houston (2009) several factors that are generally considered in making decisions about the firm value are sales stability, asset structure, leverage operations, growth rates, profitability, taxes, controls, management attitudes, lender attitudes, credibility appraisers, market conditions, internal company conditions, and financial flexibility.

CSR activity becomes very important because many investors are concerned with the environment so that the company's managers try to make the company can run its business 
without damaging the environment. The existence of various environmental damage caused by the acceleration of economic development in order to accelerate economic improvement sometimes sacrificed a lot of the natural environment. CSR disclosure of company does not give a profit or profit directly, which is expected to be a long-term benefit in the form of image or reputation of the company.

The advantage of a company that has a good reputation as an intangible assets and can improve the performance of his company (Wernerfelt, 1984). Going public companies have confidence that the company's reputation tends to increase investor appraisal, which in turn can enable companies to attract capital (Srivastava, et al., 1997 in Suta (2005). The capital is used maximally to increase the firm value. For Chen (2002) factors that can affect the firm value, including the capital structure, profitability, tax rate, capital expenditure, and firm size. Riyanto (2001) mentions the interest rate of stability of earnings, the composition of assets, the level of risk of the assets, the amount of capital required, the state of the capital market, the nature of management, and the firm size in determining the firm value.

\section{METHODS OF RESEARCH}

The location of this research is conducted in Indonesia Stock Exchange especially in mining sector by accessing official website www.idx.com. The year of research used is observation year 2012-2016. The technique used by researchers in the sample selection is nonprobability sampling that is purposive sampling. Nonprobability sampling is a sampling technique that does not provide the same opportunity / opportunity for each element or member of the population to be selected as a sample. Purposive sampling is a technique of determining samples with certain considerations. By using purposive sampling method is expected to produce sample criteria that really represent the population, in accordance with the purpose of research can solve research problems and can provide a more representative value.

\section{RESULTS AND DISCUSSION}

The data collected were analyzed by using statistical analysis tool that is moderated regression analysis. Moderated Regression Analysis is a specialized application of multiple linear regressions to determine the effect between two variables that are affected by the third variable or moderating variable (Ghozali, 2006).

This analysis is used to determine the effect of independent variables, namely capital structure (DER) and interaction variable that is capital structure with CSR disclosure to dependent variable that is firm value. Based on the results of data processing, obtained the following results on Table 1:

Table 1 - MRA Testing Result

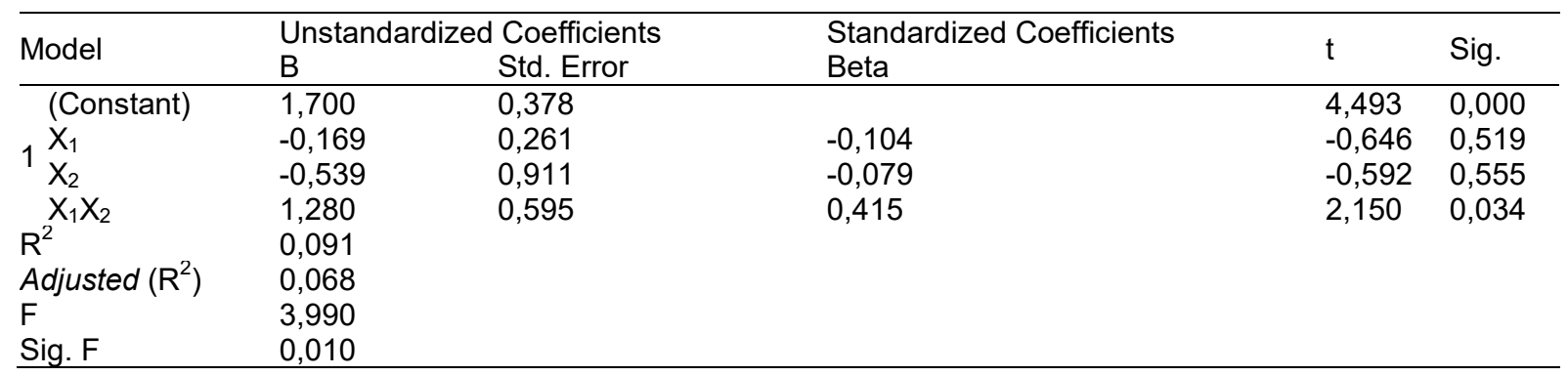

Source: Primary Data, 2017.

Based on Table 1 can be made a model of regression equation is as follows:

$$
Y=1,700-0,169 X_{1}-0,539 X_{2}+1,280 X_{1} X_{2}
$$


The result of regression analysis in Table 1 shows the coefficient of $\beta$ is 1,280 with significance level equal to 0,034 smaller than 0,05 meaning that capital structure interaction and CSR disclosure have positive and significant effect on firm value. This result proves that CSR discloses moderate and strengthen the effect of capital structure on the value of the mining company so that the first hypothesis is accepted. These results also prove that the disclosure of CSR is a pure moderating variable (Pure Moderator). This condition can be explained that the higher the CSR disclosure of the mining company, the capital structure of the company viewed from its debts can be reduced to increase the firm value.

The capital structure theory explains the company's debt-related and equity financing policies used to maximize firm value. Selection of the right capital structure will be able to improve the efficiency of capital cost and firm value and avoid the company from financial difficulties. High debt usage in the capital structure will cause the company to be in a financial distress position. Trade of theory states that the use of debt will increase the firm value but only up to a certain point, after exceeding that point the use of debt will lower the firm value (Sari, 2017). The point in question is the ability of the company to repay the loan along with its interest. Eli (2008) stated that there is no certain characteristic to determine the optimum point of debt usage in capital structure of a company, but Sugihen's research (2003: 208) stated optimum point of capital structure ranged from 0.3 to 0.4 . By using these numerical guidelines, the level of debt use in mining companies in 2012-2016 is high.

The characteristics of the mining industry require enormous, long-term, risk-bearing investment costs and high uncertainty, making funding a key issue related to enterprise development (Sakinah \& Ibrahim, 2017). Mining companies need enormous capital in exploring natural resources in developing mining. To that end, many mining companies enter the capital market to absorb the investment and to strengthen its financial position.

Theoretically, the more CSR activity expressed by the company, thefirm value will increase because the market will give a positive appreciation to the company that performs CSR which is indicated by the increase of stock price of the company. Investors appreciate CSR practices and see CSR activity as a guide to assess the company's sustainability potential. Therefore, in making investment decisions, many investors pay enough attention to the CSR expressed by the company (Ghoul, et al., 2011). By carrying out social responsibility, the company is expected to not only pursue short-term profits, but also contribute to improving the welfare and quality of life of people and the environment around in the long term. Furthermore, consistent implementation of CSR in the long run will foster a sense of public acceptance of the company's presence. One of the benefits of CSR for companies is to maintain and boost the company's reputation and brand image (Untung, 2008: 6). For a publicly listed company or a capital market issuer, the company's reputation can increase investors' valuation before deciding to invest, which in turn will make it easier for companies to earn capital (Suta, 2005).

Based on Signaling theory, the social activities disclosed by firms in the annual report provide information to investors about substantial future return prospects. Appropriate disclosure of CSR and in accordance with stakeholder expectations is a good news signal given by the management to the public and shows that the company has good prospects in the future as well as ensuring the creation of the company's going concern. The company discloses CSR in the hope of enhancing the reputation and firm value through the increase of share price (Apriwandi and Pratama, in Astuti \& Nugrahanti, 2015).

Good corporate reputation is a scarce and valuable resource, and a source of competitive advantage to get above average return (Barney, 1991). Moreover, reputation is an important part because of its wide scope and is potentially very profitable for the company because it integrates several blends considerations of finance, management, advertising and public relations (Srivastava 1997).

The results of Fombrun \& Shanle (1990) suggest that the greater a corporate contribution to social welfare environment, the better the company's reputation. In line with the results of the research of Pfeffer \& Salancik (1978), Parket \& Eibert (1975), and Cornel \& Shapiro (1987) which show the result that social and political involvement in the immediate environment of the company will positively affect the continuity of the company's operations 
and will get support from stakeholders in facing environmental challenges. The results of the Dowling (2001) study say that if a company has a reputation beyond the average, then the company can achieve superior profit. For the company that has achieved it, the reputation status will be able to help the superior profit resilience. This of course will attract the attention of investors to invest their shares in the company that has a good value. This result supported by Srivastava (1997) and Suta (2005) who found evidence of a positive effect between corporate social responsibilities on stock market performance.

\section{SUGESTIONS AND CONCLUSION}

This study shows that CSR disclosure moderates the effect of capital structure on firm value. The existence of this influence indicates that more and more companies express their social responsibility to the environment and society will further strengthen the interest of investors to invest in companies that are considered environmentally friendly and see CSR activities as a guide to assess the potential sustainability of a company, but when the capital structure of the company where the proportion more debt than its equity will be able to lower the value of the company because investors judge the company is too risky financial difficulties. If the company's debt can be reduced then it can increase the firm value. For investors to be cautious of companies that use most of the debt in the proportion of their capital structure to support the operations of the company especially if it can lower the value of the company.

\section{REFERENCES}

1. Annisa, N. I. \& Nazar, M. R., 2015. Pengaruh Struktur Kepemilikan Dengan Variabel Kontrol Profitabilitas, Umur Dan Ukuran Perusahaan Terhadap Luas Pengungkapan Corporate Social Responsibility. Eproceedings of Management, 2(1).

2. Apriada, K., 2013. Pengaruh Struktur Kepemilikan Saham, Struktur Modal Dan Profitabilitas Pada Nilai Perusahaan. Tesis.

3. Apriwandi \& Pratama, R. Y., 2011. Pengaruh Perataan Laba dan Corporate Social Responcibility (CSR) Disclosure Terhadap Reaksi Pasar. Tesis. Universitas Widyatama.

4. Astuti, C. W. \& Nugrahanti, Y. W., 2015. Pengaruh Pengungkapan Corporate Social Responsibility Terhadap Reaksi Pasar. Dinamika Akuntansi, Keuangan dan Perbankan, 4(2), pp. 90-105.

5. Barney, J. B., 1991. Firm Resources and Sustainable Competitive Advantage. Jou rnal of Management, Volume 17, pp. 99-120.

6. Brealey, R. A., C., M. S. \& J, M. A., 2007. Dalam: Dasar-Dasar Manajemen Keuangan Perusahaan. Five penyunt. Jakarta: Erlangga, p. 355.

7. Brigham, F. \& Houston, J., 2001. Manajemen Keuangan. Edisi Kedelapan. Jakarta: Erlangga.

8. Cornel, B. \& Shapiro, A., 1987. Corporate Stakeholder and Corporate Finance. Financial Management, Volume 16, pp. 5-14.

9. Dobson, J., 1989. Corporate Reputation: A Free-Market Solution to Unethical Behaviour. Business and Society, 28(1).

10. Dowling, G., 2001. Creating Corporate Reputation, Identify, Image and Performance. New York: Oxford University Press.

11. Eli, Safrida. 2008. Pengaruh Struktur Modal dan Pertumbuhan Perusahaan terhadap Nilai Perusahaan pada Perusahaan Manufaktur di Bursa Efek Jakarta. Tesis. Sekolah Pascasarjana USU Medan

12. Fombrun, C. J. \& Shanle, M., 1990. Whats in a name? Reputation Building and Corporate Strategy. Academy of Management Journal.

13. Ghoul, S. E., Guedhami, C. C. Y. K. O. \& R, M. D., 2011. Does Corporate Social Responsibility Affect the Cost of Capital?. Journal of Banking \& Finance, 35(9), pp. 23882406. 
14. Ghozali, I., 2011. Aplikasi Analisis Multivariate dengan Program SPSS. Semarang: Badan Penerbit Universitas Diponegoro.

15. Hadi, N., 2011. Corporate Social Responsibility. Yogyakarta: Graha Ilmu.

16. Heinkel, R., Alan, K. \& Josef, Z., 2001. The Effect Of Green Investment On Corporate Behavior. Journal of Financial and Quantitative Analysis, 36(4), p. 431.

17. Husnan, S., 2000. Manajemen Keuangan Teori dan Penerapan. Edisi Ketiga. Yogyakarta: UPP AMP YKPN.

18. Keown, A. J., 2004. Manajemen Keuangan: Prinsip-prinsip dan Aplikasi. Jakarta: PT. Indeks Kelompok Gramedia.

19. Luo, X. \& Bhattacharya, C., 2006. Corporate Social Responsibility, Customer Satisfaction and Market Value. Journal of Marketing, Volume 70.

20. Mamduh, H., 2004. Manajemen Keuangan. Yogyakarta: BPFE.

21. Nurlela, R. \& Islahuddin, 2008. Pengaruh Corporate Social Responsibility Terhadap Nilai Perusahaan dengan Prosentase Kepemilikan Manajemen Sebagai Variabel Moderating.Symposium Nasional Akuntansi XI Pontianak.

22. Parket, R. \& Eibert, H., 1975. Social Responcibility: The Underlying Factors. Business Horrizons, Volume 18, pp. 5-10.

23. Pfeffer, J. \& Salancik, G., 1978. 1978. The External Control of Organizations: A Resources Dependence Perspective. New York, Harper \& Row.

24. Ramlal, I., 2009. Determinants of Capital Structure Among Non-Quoted Mauritian Firms, Under Specificity of Leverages: Looking for a Modified Pecking Order Theory. International Research Journal of Finance and Economics, pp. 83-92.

25. Rosiana, G. A. M. E., Juliarsa, G. \& Sari, M. M. R., 2013. Pengaruh Pengungkapan CSR terhadap Nilai Perusahaan dengan Profitabilitas sebagai Variabel Pemoderasi. E-Jurnal Akuntansi Universitas Udayana.

26. Sari, C. M., 2017. Pengaruh Struktur Modal dan Profitabilitas Terhadap Nilai Perusahaan dengan Pengungkapan Corporate Social Responsibility (CSR) Sebagai Variabel Moderating. Tesis. Universitas Islam Negeri Maulana Malik Ibrahim Malang.

27. Sari, N. P. A. P., 2014. Faktor-Faktor yang Memengaruhi Struktur Modal pada Perusahaan Non Keuangan yang Terdaftar di Bursa Efek Indonesia.Jurnal Akuntansi Universitas Udayana., 7(1), pp. 33-47.

28. Srivastava, R. K., 1997. The Value of Corporate Reputation: Evidence from Equity Markets. Corporate Reputation Review, Volume IV.

29. Suharto, E., 2009. Pekerjaan Sosial di Dunia Industri: Memperkuat CSR (Corporate Social Responsibility).Bandung: Alfabeta.

30. Sulistyowati, W. A., 2009. Penentuan Kebijakan Struktur Modal Pada Perusahaan Manufaktur di Bursa Efek Indonesia.

31. Suta, I. P. G. A., 2005. Kinerja Pasar Perusahaan Publik di Indonesia: Suatu Analisis Reputasi Perusahaan. Disertasi.Universitas Indonesia.

32. Untung, H. B., 2008. Corporate Social Responsibility. Jakarta: Sinar Grafika.

33. Wardianto, K. B., 2012. Pengujian Teori Struktur Modal pada Perusahaan-Perusahaan 50 Biggest Market Capitalization di Bursa Efek Indonesia. Seminar Hasil-Hasil Penelitian dan Pengabdian Kepada Masyarakat-Dies Natalis FISIP Unila.

34. Weston, J. F. \& Copeland, T. E., 1992. Dasar-Dasar Manajemen Keuangan. Erlangga. 